\title{
Fallen Love: Eros and Ta'wīl in the Poetry of Robert Duncan
}

\author{
Ross Hair \\ University of East Anglia
}

This article examines Robert Duncan's erotic poetics in the context of his interest in an elite "Spirit of Romance" and "Cult of Eros" that he recognizes in Lucius Apuleius, the Provençal troubadours, Dante and the Fedeli d'amore, as well as in his modernist forbears, particularly Ezra Pound, who coined the term "the Spirit of Romance." In his explication of this tradition, Duncan has drawn on the ideas of the religious scholar Henry Corbin, particularly his work on the "Visionary Recitals"-the spiritual autobiographies and commentaries associated with the thirteenth-century Persian philosopher Avicenna. Focusing on Corbin's notion of ta'wīl, a method of textual exegesis that forms the keystone of his work on Arabic religious esotericism, this article examines the typological affinities that Corbin's scholarship shares with Duncan's erotic poetics. Via close readings of Duncan's poems "Poem Beginning with a Line by Pindar," "The Torso," and "Circulations of the Song," this article argues that Corbin's work provides a pertinent corollary to Duncan's erotic poetics.

Kewords: Robert Duncan / Henry Corbin / eros / hermeneutics

In "Opening the Dreamway," his 1983 lecture for the Analytical Society of Western New York, Robert Duncan (1919-1988) remarks that with "Corbin being conveniently dead, you could start enrapturing yourself or what with detritus from Corbin" (20). ${ }^{1}$ Duncan is referring to Henry Corbin (1903-1978), the French scholar of religion who was, Tom Cheetham writes, "at once a Neoplatonic philosopher, a theologian with interests in Immanuel Swedenborg and Johan George Hamann, Jacob Boehme and Martin Heidegger, and an Orientalist specializing in Islamic mysticism" (vi). Duncan evokes Corbin in the context of his friend Norman O. Brown (1913-2002), who, Duncan claims, "gives lectures on Islam, alarming to the people who are actually in Islam" (20). These lectures, recently collected and published in The Challenge of Islam: The Prophetic Tradition (2009), draw extensively on Corbin's work.

Duncan's use of the word "enrapturing"-from rapt, meaning to be carried away by force, and sharing the same root as "rape" and "ravish" - reflects how, as Stephen Fredman notes, Duncan reads Brown's earlier book, Love's Body (1966) as "a poetics of eroticism" concerned primarily with "the symbolic transfer of energies from sexual to the political to the cosmic and back again" (29). Brown's later lectures are "alarming" because they continue to elaborate on this "erotic poetics" by finding examples in Islam. As Jay Cantor suggests, Brown found in Islam's esoteric currents suggestions of "a different way (in Ibn Arabi and Sufism) of how an erotic body consciousness might be described" that reiterate his ideas about Eros (x). In particular, Corbin's ideas concerning the theophanism of the Shi' ite Sufi Ibn Arabi in Alone with the Alone: Creative Imagination in the Süfism of Ibn 'Arabi (1969) resonate with Brown's emphasis on an "erotic mysticism that grounds its symbolism in something instead of seeking transcendence" (Fredman 24). As well as grounding an eros-centred mysticism in tangible forms, Corbin's theophanism also complements and furthers a "mystical eroticism that [Brown] aligns with the gnostic or hermetic tradition in Western culture" (Fredman 24). Although Brown's prime figures are William Blake and Jacob Boehme, a significant and not unrelated branch of this tradition, Arthur Versluis suggests, concerns a "sophianic mysticism or religious eros," rooted in courtly love and troubadour poetry, in which "religious knowledge, chivalric mythology, initiatory wisdom, asceticism, and love were all condensed" (30).

Duncan's own reading of Corbin, upon whom he had been "enrapturing" himself since 1961, dovetails with these assessments of Brown's enquiries into Eros. The manifold attributes that Denis De Rougemont identifies with Eros - "complete desire, luminous Aspiration, the primitive religious soaring carried to its loftiest pitch, [and] the extreme exigency of purity which is also the extreme exigency of Unity"-are also instructive forces, or powers, throughout Duncan's poetry (61). In all His manifestations - as a primal Orphic cosmic power (Phanes-Eros), a Platonic ideal (the Beloved), as well 
as the classical god (son of Aphrodite, companion of Psyche) and as erotic desire-Eros is, I propose, the "major mover" of Duncan's poetry $(O F 11)$. Building on Fredman's insights regarding Duncan's erotic "contextual" poetics, I want to consider the tacit role Corbin assumes in Duncan's own ideas about the "primary eroticism of poetry" (27). To do so, I will focus primarily on how Duncan has read Corbin's book, Avicenna and the Visionary Recital (1960), which Robin Blaser gave him in 1961 (Bertholf 337). ${ }^{2}$ Duncan uses Corbin's book in his engagement with the cult of Eros and its pronounced angelology in a section of The H. D. Book dating back to March 1961. ${ }^{3}$ Duncan also evokes Corbin in several poems included in Bending the Bow (1968) and in Ground Work: Before the War (1984). Considering these poems in relation to what is perhaps Duncan's defining "erotic" poem-"Poem Beginning with a Line by Pindar" from The Opening of the Field (1960)_- I propose that Duncan's erotic poetics, by invoking what is essentially a syncretistic tradition of Eros-centred theosophies and Neoplatonic cosmologies, addresses the question of "fallen love." This refers to an earthly, material love, itself reflecting the Divine Love with which individuals (or, their souls) aspire to reunite. It also denotes what De Rougement in Love in the Western World (1940) describes as a historical descent of "passionate love":

The history of passionate love in all great literature from the thirteenth century down to our own day is the history of the descent of the courtly myth into "profane" life, the account of the more and desperate attempts of Eros to take the place of mystical transcendence by means of emotional intensity. But magniloquent or plaintive, the tropes of its passionate discourse and the hues of its rhetoric can never attain to more than the glow of a resurgent twilight and the promise of a phantom bliss. (170)

As a historical condition and as a cosmic force, "Eros, like Osiris or Lucifer (if He be the Prince of Light whom the Gnostics believe scattered in sparks throughout the darkness of what is matter)," Duncan claims, "is a Lord over us in spirit who is dispersed everywhere to our senses": "We are drawn to Him, but we must also gather Him to be" (HD 82). The poet therefore has to retrieve and re-member this "fallen love" within "the creative work of a union in knowledge and experience" (HD 82). As I argue, not only does Corbin engage similar themes of exile and return in various forms of Arabic esotericism, but he also identifies and promotes a method of textual exegesis - the Arabic concept of $t a$ ' $w \bar{l} l$ - which is fundamental to their gnosis. Ta'wìl, I argue, provides an implicit corollary to Duncan's recuperative poetic which "participates in the erotic energy underlying not only the experience of love but all life" and "take[s] in and imaginatively inhabit[s] the entire spectrum between eros and thanatos" (Fredman 177, 166).

\section{The Visionary Recital}

Avicenna and the Visionary Recital comprises Corbin's translations of the "Visionary Recitals" and the accompanying commentaries attributed to the Persian philosopher Ibn Sinna (Avicenna) as well as Corbin's extensive explication of their complex hermeneutics. These Recitals, such as The Recital of the Bird and The Recital of Hayy ibn Yaqzan, are spiritual autobiographies or mystical accounts, that articulate what Christopher Bamford describes as "Avicenna's Neoplatonized Aristotelianism" which attempts to "impose the intelligible universe of Neoplatonism, proceeding by contemplation, upon Aristotle's more sense-based world" in order to delineate a "theoretically elaborated cosmos [not as] an abstract construct but [as] a lived, phenomenal reality" (Voyage xxvi, xlviii).

According to Bamford, the Recital expresses "a complicity between angelology and cosmology" that "ontologize[s] nature and consciousness as a single structure, confirming the essentially spiritual nature of humanity and the soteriological structure of the cosmos" (Voyage xxvii). The Recitals are essentially anagogic narratives that describe journeys of exile and return. Travelling through a spiritual and symbolic topography, the narrator of the Recital expresses how the soul is connected to, and mediated by, a hierarchy of angelic Intelligences that lead back to the divine One. As Bamford explains, "by means of contemplation and endowing the cosmos - the world of human experiences - with a spiritual, angelological (that is, ontological) correspondence" the traveler's soul returns to its divine origins 
(Voyage xxvi). It is at this point that theophany proves crucial to such an event because a "to conceive the universe and intelligible essences" within the Recital is "complemented by imaginative ability to Visualize concrete figures, to encounter "persons"" so that "the soul reveals all the presences that have always inhabited it without its being aware of them" ( $A V 8)$. This "acquisition of consciousness," Corbin suggests, "permits the soul triumphantly to pass beyond the circles that held it prisoner" $(A V 8)$. "And that," Corbin proposes, "is the entire adventure related, as a personal experience, in the Recital of Hayy ibn Yaqzan and the Recital of the Bird" (AV8).

\section{The Spirit of Romance}

In The H.D. Book Duncan reiterates Corbin's emphasis on "personal experience" in the context of the "cult of angels" which occurs within a transhistorical "Spirit of Romance" that attributes, "absolute value $[\ldots]$ to the individual experience that would imagine the universe in terms of love, desire, devotion, and ecstasy" (520). Duncan derives the phrase "Spirit of Romance" from Pound's book of the same name (first published in 1910) which traces a cult of Eros or Love "from the Golden Ass of Apuleius and from the Pervigilium Veneris of the second-century A.D. through to Dante and Guido [Cavalcanti]" (Selected Prose 155). From this Spirit of Romance a new conception of Love emerges:

Romance has appeared, and there may be a new Eros. Not only the primal cosmic power but also the Platonic ideal, the First Beloved, but also the most human god that Psyche sought, but also the Eros as evil that Church fathers, Catholic and heretic, had imagined, but also now the power of a cult that remains as a mode in poetry. Eros had become a tradition of the poem. (HD 95-96)

Duncan sees Pound's generation as inheritors of this "tradition of the poem" which was passed onto them from the Pre-Raphaelites: "Back of H.D., as back of Pound or of Yeats, was the cult of romance that Rossetti and then Morris had derived from Dante and his circle, the Fedeli d'amore, and revived in the Victorian era" (HD 519). ${ }^{4}$ Just as the modernists received the tradition from their Victorian predecessors, Duncan sees himself and close contemporaries including Robert Creeley, inheriting it from their modernist forbears (Selected Prose 155). Indeed, "Sonnet 3" from Roots and Branches (1964)Duncan's reworking of Dante's sonnet, "Guido, i'vorrei che tu e Lapo ed io," addressed to Robin Blaser and Jack Spicer - promotes an Erotic coterie in its celebration of homosexual fraternity and its testimony to "a primary poetic vision and experience that will return where it will in man's history" ( $R B 124 ; H D$ 97).

The Spirit of Romance comprises an "aristocracy of emotion" encompassing various poetic milieus including the Provençal troubadours, the Tuscan poets known as the Fedeli d'amore - the faithful followers of Love who practiced the dolce stil novo, the "sweet new style" of poetry-and, their most celebrated affiliate, Dante (SR 90). Unlike the "erotic poetics of the New American poets" that, Fredman claims, "marks a rebirth of Whitmanian virtues of informality, openness, vulnerability, nakedness, ecstasy, and camaraderie," the Spirit of Romance is elite and circumscribed (6). Closed, hermetic forms such as the troubadours' trobar clus, and the "visionary interpretation" they required, ensured only a specialized readership could grasp Love's divine mysteries (SR 90). Likewise, the Fedeli d'amore, William Anderson writes, was "open to a few," those "rare spirits who were struggling to devise a code of life that retained from chivalry the idea of nobility, while making it depend on personal virtue instead of inherited wealth and breeding" also "preserved spiritual aspirations not unlike that of some mendicants" (80). But their "insistence on the nobility of the heart rather than nobility of descent," Anthony Mortimer notes, "does not involve any democratization of poetry" because these Tuscan poets saw "themselves as a cultural and spiritual elite" and "shared the Provençal love of formal complexity" which ensured their code of love was not profaned by base minds $(153,151)$.

This elite gnosis emphasizes an experiential Love, an "interpretation of the cosmos by feeling," which is felt as a spiritual reality via the mediation of a female figure (SR 94). Recalling how in the Visionary Recital the "figure that announces itself to the soul personally [...] symbolizes with the soul's most intimate depths," Duncan proposes that in the Spirit of Romance, "The Spirit or the sacred in man's 
being appeared in the old order as a woman, an angelic presence or Truth in which a man took his being, as Dante took his being in Beatrice" (AV 20; HD 516). This "Truth" in Dante's Vita Nuova, Roxanna Preda notes, is Love itself, "an anthropomorphic, male, para-Christian deity that appears in dreams and visions and dictates conduct" (47). Corbin describes a similar anthropomorphism in terms of theophany, noting how "a phenomenology of the stranger-consciousness" manifests in "[w]orks of philosophy, spiritual romances in prose, or mystical poems" as "a fundamental gnostic intuition, which in every relation individualizes the Holy Spirit into an individual Spirit, who is the celestial paredros of the human being, its guardian angel, guide and companion, helper and saviour" (AV 27, 21).

Duncan also recognizes Eros as "a primal authority, a cosmic need," and a "formal demand" which is realized in a law (or lure) of desire and attraction that "shape[s] all matter to its energies" (HD 82, 71). This perception of Eros as both a cosmic and a personal phenomenon adumbrates Duncan's notion of "a poetic faith in which Eros and Poetry, Romance, Rite and Lore have become One in the imagination" (HD 98). Fredman draws attention to this aspect of Duncan's poetry in the context of what he considers the "self-reflexivity" of Duncan's erotic poetics (28). According to Fredman, this selfreflexivity "has much in common with the cult of love because both pursuits involve an erotic turning inward that increases the power of the activity by concentrating on its own properties rather than on the outside world" (28). The broader implications of Duncan's self-reflexive erotic poetics are evident in Davidson's suggestion that, for Duncan, poetry itself "instantiates a ritual 'scene of instruction' that inaugurates the poem and becomes one of its central subjects":

In its most common form, the scene opens with the poet engaged in reading (or, in some cases, in writing) a text, whereupon lexical or philological questions about individual words disturb concentration and permit entry into a deeper level of comprehension. The poet returns to a "place of first permission" where suppressed meanings provide access to a larger vision of things. Those meanings include archaic survivals of cultic and atavistic religions which propose a unity of spirit and form, of soul and eros. ("Marginality" 279)

This kind of self-reflexivity, as I discuss below, is evident in Duncan's poem "Poem Beginning with a Line By Pindar" which, out of all the contingent factors of composition, becomes "a powerful nexus" of the "transcendent reality of Eros and Psyche and of the revelations flowing out of the myth they belonged to" ( $F C$ 17). This poem, therefore, not only demonstrates how poetry instantiates a rite in which "Eros and Poetry, Romance, Rite and Lore [...] become One in the imagination," but also discloses hermetic meanings, or a gnosis, concerning the cult of Eros within which "soul and eros" are major, defining, powers and players.

\section{Ta'wīl}

Corbin also recognizes reading as the scene of ritual instruction. Indeed, what Davidson identifies as an instructive reading practice motivating Duncan's poetics is paralleled in the $t a$ 'w $\bar{l} l$ which Corbin understands as a textual exegesis and "the most characteristic mental operation of all our Spirituals, Neoplatonists, Ishraqiyun, Sufis, [and] Ismailian theosophists":

Its process is best fitted to reveal to us both the secret of the genesis of our visionary recitals (since it also provokes the situation that originates them) and the secret of deciphering them. The operation properly consists in "bringing back," recalling, returning to its origin, not only the text of a book but also the cosmic context in which the soul is imprisoned. The soul must free this context, and free itself from it, by transmuting it into symbols. (AV 28)

$T a$ 'wìl, is implicit throughout Duncan's work. In "Moving the Moving Image, Passages 17," from Bending the Bow, Duncan uses the term "Mi'raj" to describe the sun's ascent which becomes commensurate with the ascent of the enraptured speaker's heart: "Grand Mi'raj! It is the Sun, the fiery 
ball / that ascends with my heart" (BB 60). According to Corbin "Mi'raj" denotes the gnostic's anagogic ascent - their journey of Return:

The ta'will of the soul - the exegesis that leads the soul back to its truth (haqiqat) - transmutes all cosmic realities and relations and restores them to symbols; each becomes an Event of the soul, which, in its ascent, its Mi'raj, passes beyond them and makes them interior to itself. (AV 34).

Ascent and interiorization are not, however, antitheses in the gnostic ascent. "We imagine transcendence on the basis of height," Pierre Deghaye writes, "but it exists no less in the depths. On the other hand, depths also exist in interiority. What is interior is transcendent in relation to what is exterior" (217). Notably, Davidson describes Duncan's poetry as permitting "entry into a deeper level of comprehension," and Duncan draws attention to a similar notion of depth in "The Sweetness and Greatness of Dante's Divine Comedy" (1965):

If we view the literal as matter of mere fact, as the positivist does, it is mute. But once we apprehend the literal as a language, once things about us reveal depths and heights of meaning, we are involved in the sense of Creation ourselves, and in our human terms, this is Poetry, making, the inner Fiction of Consciousness. (FC 145)

Ascent/descent is also evident in the image of the sun Duncan presents in "Benefice, Passages 23" which, "on the horizon / in the West // (setting) / rises" (BB 76). Notably, this sun rises "from the Orient West of us" (BB 76). Corbin's uses the term "Orient" to describe the spiritual orientation of ta 'wīl: "[B]eneath the idea of exegesis we glimpse that of an exodus, of a 'departure from Egypt,' which is an exodus from metaphor and the slavery of the letter, from exile and the Occident of exoteric appearance to the Orient of the original and hidden Idea" (BB 76; $A V 29)$. This "exodus" is achieved through the hermeneutics of $t a$ ' wìl which, Corbin emphasizes, "is, etymologically and inversely, to cause to return, to lead back, to restore to one's origin and to the place where one comes home, consequently to return to the true and original meaning of a text" (AV29).

What Corbin describes is not without precedent or equivalents. For example, the emphasis Corbin places on a text's exoteric and esoteric meanings recalls the "closed," hermetic, compositions of trobar clus that, Roger Boase explains, "lends itself to interpretation on many levels" and, according to Frank M. Chambers, "demands more than ordinarily acute receptivity on the part of the reader" (78; 96-97). Indeed, the elite "inner rite" of trobar clus and its "heretical language where meanings were united in a spiritual double-entendre" parallel the extraordinary demands of ta' will (HD 91). According to Corbin, only the exegete who has "first acquired a perfect understanding of the "data' which the literal revelation (tanzill) provides," and "who is fully appraised of the modalities according to which the universes intercorrespond, as well as the meaning of the anamnesis to be found in all of them" can perform ta'will (Temple 39).

Although it seems credulous to presume a "true and original meaning of a text," Duncan's poetry expresses its own exodus from the slavery of the letter. In his program notes for a 1959 reading at San Francisco State College's Poetry Center, Duncan posits a transcendent/hidden archetext:

A poem is news of an other life. And from childhood I have been seeking the lore of that other life, with a faith that everything that is realized here $i s$ there, and real only there - thus I call it the real world: that everything we do here, each act, the actual world, is a sign, an omen of the real, and an enactment of its reality, as actual words in actual script or print on the actual page are signs of a real spiritual world. (173-174)

Language not only describes an "other" reality but is that reality. Exegesis, therefore, is integral to how that other life, the spiritual reality of Poetry, is realized. Thus, as Corbin suggests, "instead of seeking a secret in or under the text, we must regard the text itself as the secret" (AV 33). In Duncan's case, this 
means that at back of each poem is the intimation of a more encompassing Poetry. To recall Davidson's claims regarding Duncan's "ritual 'scene of instruction," each poem, in its writing or its reading, becomes an occasion for what is essentially $t a$ ' wĭl, a method and a rite of intuiting the larger orders concealed within a text.

These similarities with $t a$ 'wìl are perhaps most striking in Duncan's introduction to Bending the $B o w$, particularly in his description of the poem as a dark room "alight with love's intentions" ( $B B$ vii):

It is striving to come into existence in these things, or, all striving to come into existence is It - in this realm of man's languages a poetry of all poetries, grand collage, I name It, having only the immediate event of words to speak for It. In the room we, aware or unaware, are the event of ourselves in It. ( $B B$ vii)

Duncan also voices these ideas in "The Sweetness and Greatness of Dante's Divine Comedy," claiming that, "the universe and our experience in it is a text that we must learn to read if we are to come to the truth of it and ourselves" (FC 144). Corbin makes a similar claim in the context of the gnostic's soul in the Recital which "takes its departure, accomplishes the $t a$ ' wìl of its true being, by basing itself on a text - text of a book or cosmic text - which its effort will carry to a transmutation, raise to the rank of a real, but inner and psychic, Event" ( $A V 31)$. But whether $t a$ 'wìl can really achieve such a return to "real" truth and meaning is not as important as the stance such exegesis implies. For, as Corbin suggests, the orientation of $t a$ ' wìl refuses to limit "the field of true and meaningful knowledge to the mere operations of the rational understanding":

Freed from an old impasse, we have learned to register and to make use of the intentions implicit in all the acts of consciousness or transconsciousness. To say that the Imagination (or love, or sympathy, or any other sentiment) induces knowledge, and knowledge of an 'object' which is proper to it, no longer smacks of paradox. (Alone 3)

\section{The Angel}

The dialectical relationship of the actual with the spiritual - those depths and heights of meaning witnessed in the literal - defines the Spirit of Romance and its emphasis on the figure of the Beloved. "In the tradition of the mystery poem that Pound traces from Apuleius to Dante the figure of a woman is central," Duncan notes: "Isis, then the Venus of the Pervigilium Veneris, the Lady of the troubadours and Beatrice" (HD 512). Duncan outlines a similar legacy in his poem "The Maiden" in The Opening of the Field whose image of a maiden "Bright with spring," recalls the verdant imagery used to describe the Lady of the troubadours and the Fedeli d'amore. Dante's friend, Guido Cavalcanti and fellow Fedeli d'amore, in his ballata, "Fresca rosa novella" stresses how the Lady becomes a mediatrix when he writes: "Angelic form, I say, / Lady, resides in you" (3). In such instances, as Duncan explains in The H. D. Book, the lover is "united with the divine reality by a love union with the Angel who is present in the person of the Beloved" (520). In the figure of the Beloved theophany occurs; Love manifests Itself through love, desire, and beauty. This "Lady is both archetypical and specific," Duncan suggests in an essay acknowledging Creeley's place in the Spirit of Romance, which indicates how "poetry arises in the constant working of a tangible substance and idea at tension" (Selected Prose 155).

Corbin's influence on Duncan's ideas about this tradition is implicit in Duncan's suggestion that "Dante drew from translated Sufi texts as well as from the songs of Toulouse and Albi where such images of the First Beloved appeared" (HD 519, 521). While this recalls Pound's claim in "Cavalcanti" (1934) that Cavalcanti's ideas are traceable to "the Arabian background" of Avicenna, "the concentric spheres of the heavens, Ibn Baja's itinerary of the soul going to God, [and] Averroes' specifications for the degrees of comprehension," it also reflects Corbin's claims regarding the intersection of Arabic theosophy with the Fedeli d'amore (LE 149, 158). Corbin frequently uses the term "Fedeli d'amore" to describe the eroscentred theophanies in various Arabic traditions, including the Visionary Recital, as well as "Ibn 'Arabi, 
the incomparable master of mystic theosophy, and Jalaluddin Rumi, the Iranian troubadour of that religion of love whose flame feeds on the theophanic feeling for sensuous beauty" (Alone 110):

Fedeli d'amore struck us as the best means of translating into a Western language the names by which our mystics called themselves in Arabic or Persian ('ashiqun, muhibbun, arbab al-hawa, etc.) Since it is the name by which Dante and his companions called themselves, it has the power of suggesting the traits which were common to both groups and have been analyzed in memorable works. (Alone 110)

Corbin, however, is more concerned with identifying "the undeniable typological affinities between them," the Oriental and the Occidental Fedeli d'amore, rather than their "actual historical relations" (Alone 100). One key affinity is "the experience of a cult of love dedicated to a beautiful being is the necessary initiation to divine love, from which it is inseparable" and which "is a unique initiation, which transfigures eros as such, that is, human love for a human creature" (Alone 101). This adumbrates Duncan's claim, derived from Plato's Symposium, that "love is most true when addressed in the name of the First Beloved, the One because of Whom we love" (HD 488). The implications of such mediated love are sketched out at length by Corbin in Avicenna and the Visionary Recital:

[W] hat the Fedeli d'amore saw was at once the Angel Intelligence-Wisdom and some particular earthly figure, but this simultaneity was actual and visible only to each one of them. The organ of such a perception is not the sensible faculties but the active Imagination; the sensible is not thereby abolished, but transmuted into symbol; correlatively, the intelligible can reveal itself to the mental vision of a human soul only through an Image-symbol, yet without this making it necessary to say that it is merely a symbol; rather, it has all the eminent value of a symbol. ( $A V$ 269)

What these faithful followers of love have witnessed is what Guido Cavalcanti describes as "Beauty's divinity made manifest" (11).

\section{Commingling Souls}

For Duncan, however, the Beloved is male. "For," he claims in "The Torso, Passages 18," "my Other is not a woman but a man" $(B B$ 65). This is a claim Duncan returns to in his later poem, "Circulations of the Song: After Jalāl al-Dīn Rūmī” in Ground Work: Before the War:

But if you are the lover, how entirely you are $\mathrm{He}$.

How entirely He is here; He commands me. ( $G W 167)$

In contrast to the summer solstice of "Benefice," "Circulations of the Song," with its reference to the star Fomalhaut, takes place in the darkness of winter solstice which also expresses the poem's speaker's own sense of mortality (168). But from such darkness, "the Lord of Night / stirs with verges of a radiance / that is in truth dark, / darkening glances of an obscurity / Love seeks in love" (GW 170). "He," Eros, Duncan writes, "wingd and / dark ascendant," is intimated in the "mortal" love the poet expresses for his "companion of the way" (167). Thus, unlike the intellectual love expressed by Dante or Cavalcanti, the love celebrated in "Circulations of the Song" is a consummated one. ${ }^{5}$ The speaker addresses his Beloved, claiming that "in you I come true" and describes "the confused joyous rush / of coming to myself in you" $(175,168)$. But that notion of "coming to myself in you" breaks down demarcations between self and other in a manner equivalent of the "synchronism" that, in the Recital, occurs "between the soul's awakening to itself and its visualization of its Guide" ( $A V 20)$.

This syzygy is emphasized in Duncan's poem through subtle rhyme - "He" and "me," for example, and "my" and "eyes" - as well as in the dizzying oscillations the poem makes between subject and object: 
His are the eyes of my seeing you,

yours was the mouth of the wish the tongue of my speech sought

that may never actually have been yours $(G W 169)$

The blurring of Lover and Beloved recalls the "commingling" of soul's that occurs in Duncan's earlier poem "The Torso" and the paradisal path of the Beloved's body:

\author{
his soul commingling \\ I thought a Being more than vast, His body leading \\ into Paradise, his eyes \\ quickening a fire in me, a trembling \\ hieroglyph $(B B 63)$
}

This, the Beloved's "body leading / into Paradise," echoes Corbin's description of $t a$ ' wìl in "Cyclical Time in Mazdaism and Ismailism" (1957):

Thus coming into this world has meaning only with a view to leading that which is metaphoric back to true being, and the external (exoteric, zahir) back to the internal (esoteric, batin), by means, of an exegesis ( $t a^{\prime}$ will) which is also an exodus from existence. Here, then, we have a mode of understanding (modus intelligendi) in which a mode of being (modus essendi) is expressed. Even while one is materially present in this world, there is a mode of being in Paradise but it goes without saying that this mode of being, Paradise, can be realized, can exist "in the true sense," only in a person who precisely is this Paradise - that is to say, who always personifies this mode of being. (Cyclical 51-52)

Duncan would have been familiar with this, Corbin's discussion of the thirteenth-century Persian philosopher Nasir Tusi, in the context of Olson's poem "Maximus at the Harbor" which weaves into its text an angelology derived from Corbin: "Paradise is a person. Come into the world. / The soul is a magnificent Angel" (Maximus 240). This informs the poem's theme of "apophainesthai"-a Greek term, reminiscent of the Orphic "phanes," meaning, "that which shows forth"-and the enrapturing that occurs in the sexually aggressive context of rape (Butterick 354). In the poem's feminized landscape, Okeanos mercilessly "tears" in order "to get love loose" and commits "rape until love sifts" and is shown forth in Dogtown's topography (Maximus 240). Thus, Corbin's truncated phrase, "Come into the world," suggests, simultaneously, a past action, an invitation, and sexual climax.

However, in "The Torso" and "Circulations of the Song" angelology occurs through sympathy and sexual "commingling"- which, phonetically, suggests "coming"-rather than violation. The lover finds himself, physically and ontologically, in the Beloved. Thus, Greg Hewett writes, the "trembling hieroglyph" in "The Torso" suggests "not only an ancient, hermetic connection between the symbolic process and the physical, but one that is charged and indefinite - so indefinite that it is unclear which of the two bodies or both together are represented by the hieroglyph" (Hewett 540).

In "Circulations of the Song," however, a third party, Love Himself, is announced. Recalling his claim in The H.D. Book that "We are drawn to Him, but we must also gather Him to be," Duncan writes (82):

He too seeks you out. He too dreams of coming to this fugitive morning, of finding His "Self" in a Time so personal it is lost in our coming into it. (171) 
In the commingling of Lover/Beloved a theophany occurs. Love manifests tangentially, as the repetition of "coming" suggests, in the throes of a "personal" love. In the "fugitive morning" Duncan presents an equivalent of the Recital's narrator who witnesses a "figure [that] represents the heavenly counterpart of the soul," manifesting "itself to the soul only at the dawn, the 'sunrise,' of the soul's perfect individuation, its integration, because only then is its relation to the divine individualized" ( $A V 21)$. Recalling this kind of encountered/encountering gnosis, Norman Finkelstein suggests that what is witnessed in "Circulations of the Song" "is both a subjective force of ecstatic inspiration and an objective vehicle for that inspiration" (Utopian 78). What "begins as a personal revelation is made into a concrete universal, not to be asserted in abstraction, but to be re-enacted in lived experience, including the encounter with linguistic form" (79).

\section{"Poem Beginning with a Line by Pindar"}

What Finkelstein identifies in "Circulations of the Song" as "a concrete universal" encountered in "linguistic form" is also expressed in Duncan's earlier "Poem Beginning with a Line by Pindar" (c. 1958) which, according to Davidson, is "the central poem for Duncan's poetics and cosmology" ("Book" 83). Informing this poetics and cosmology is the legend of Cupid and Psyche which represents a mythopoeic archetype of the kind of personal encounters - between Lover and Beloved - that Duncan addresses in "Circulations of the Song" and "The Torso."

"Poem Beginning with a Line by Pindar," Davidson suggests, is a "multileveled reading of a primary text through its appearance in various other versions" (San Francisco 142). Duncan derives his primary story from Apuleius' version in The Golden Ass, substituting Eros for his Roman equivalent, Cupid (FC 17). Duncan charts the "fate" and "passion" of the archetypal couple in a transhistorical milieu, finding intimations, clues, and rimes of the couple's passion in the poetry of Whitman, Williams, and Pound; Goya's painting Cupid and Psyche; contemporary American politics; the legends of the American West; Duncan's family history; and the omens of his Atlantean dream (OF 66). Very much like the Pindar ode which instantiates it, "Poem Beginning with a Line by Pindar" is itself "an accumulation of metaphor" that finds in "old voices" survivals of an ancient story, and gnosis, that still directs the heart (OF 69).

Indeed, via its accumulation of salient "tropes" and "hues," "Poem Beginning with a Line by Pindar" rehearses the decline of "passionate love" that De Rougement charts in Love in the Western World (170). According to Davidson the poem presents a meditation on "the origins of love and on the historical forces that diminish its power," as well as a dramatization of "the transformation of spirit into history or the reification of time into causality" (San Francisco 142). But Duncan's poem also conveys optimism for the renewal of Love's diminished powers in the figure of the children "clockwise and counter-clockwise turning" in a dance of cosmic renewal (OF 69).

Related to this promise of renewal in Duncan's poem is a familiar trope in Gnostic, Neoplatonic, and Avicennan cosmologies concerning the soul's (the psyche's) lapse into history. Indeed, Psyche's plight in "Poem Beginning with a Line by Pindar" is one that is mirrored in the Avicennan Recital and its "motif of Return":

This motif of Return presents two implications: in the first place, the feeling of a kinship with the divinity, with celestial beings, forms of light and beauty, which for the gnostic are his true family; in the second place, and in consequence, the soul, which thus at last finds itself, experiences itself as exiled, terrified and disoriented by and among the common norms, which assign to human beings reasons for existence and goals that are completely strange to its true condition of Stranger. (AV 19)

Suffering her own exile in the "Pindar" poem, Psyche's situation like the gnostic's of the Recital. In both instances, the soul goes from ignorance and forgetfulness to an estranging but motivating consciousness of loss and then desire. Psyche's awakening occurs in the "carnal fate that sends the soul wailing / up from blind innocence, ensnared / by dimness / into the deprivations of desiring sight" (OF 
62). Thus, Psyche's "exile from Eros," her "exile from delight," is also a Fall from blissful unawareness (being, happily, in the dark) into the painful light of love: "The great dark reality in which body, soul, and spirit had been one in unknowing was reft" (HD 86). Like the Sophia (Wisdom) of Christian Gnosticism who falls from her heavenly origins into the material world of the demiurge, exiled there until Christ redeems her, Psyche strives to be reunited with Love. Indeed, for the Platonist Thomas Taylor, in Apuleius "the very ancient dogma of the pre-existence of the human soul, its lapse from the intelligible world to the earth, and its return from thence to its pristine state of felicity, are most accurately and beautifully adumbrated" (xi).

But "Poem Beginning with a Line by Pindar" is not simply about Psyche's "passion, dismay, longing, search" but is a text that repeats that passion in the very processes of the poem itself (OF 67). For, the poem is "not only a story that expresses the soul but a story that awakens the soul to the real persons of its romance, in which the actual and the spiritual are revealed, one in the other" $(F C 31)$. Reading "Poem Beginning with a Line by Pindar" in light of Corbin's notion of ta'wil effectively highlights the way in which the poem's primary text makes this revelation apparent. Indeed, Robert Kelly claims that "Poem Beginning with a Line by Pindar" performs a " $t a$ 'wìl of its own first line" ("Ta'wīl" 115). However, Duncan's poem predates the English translation of Avicenna and the Visionary Recital by two years. Nevertheless, to adopt Corbin's approach to the Fedeli d'amore, one can identify "typological affinities" between Corbin's understanding of ta'wīl and Duncan's retrospective reading of his poem. As I discuss below, Duncan's most insightful reflections about the conception of his poem occur in two essays written after The Opening of the Field: "Towards an Open Universe" (1964) and "The Truth and Life of Myth" (1968). Guy Davenport inadvertently suggests how Corbin might figure in Duncan's retrospective accounts of his poem:

Instigations are deceptive guides into imaginative structures, and the maker of the structure may be a deceptive guide. The imagination sees with the eyes of the spirit; the maker, finished his making, must then see what he has done, like the reader with corporeal eyes" (236).

It is possible that Corbin's model of $t a$ 'wìl may have given Duncan a way to valorize some of that "spirit" as he reflects on his poem. But, whatever the case, $t a$ ' wìl is a rich corollary to this defining poem of Duncan's erotic poetics.

\title{
Searching Psyche
}

To recall, a key condition in the fin amor of the troubadours and the Fedeli d'amore is desire. Duncan evokes a similar sentiment when he claims: "the information flows / that is yearning" (OF 69). This suggests that information is yearned for and that yearning itself yields information. Duncan reiterates this in a section of his poem "The Propositions" entitled "The Keeping" in The Opening of the Field: "It is from longing my making proceeds" (OF 36). This longing, which Duncan proposes, is a "magic [that] proceeds from the heart" and a "thirst that defines Beauty" suggests the kind of erotic desire motivating "The Torso" and "Circulations of the Song" (OF 37):

\author{
Finders Keepers we sang \\ when we were children or were taught to sing \\ before our histories began and we began \\ who were beloved our animal life \\ toward the Beloved, sworn to be Keepers. (OF 68)
}

As the refrain of the children's rhyme, "Finders keepers, losers weepers" suggests, loss is a prerequisite for loving. We only truly value something when its loss is tangible.

As a "drama of loss and search" the story of Eros and Psyche emphasizes this lesson, which Psyche has to learn the hard way (HD 80): 
Psyche before her sin is a dilettante. To read, to listen, to study, to gaze was all part of being loved without loving, a pleasure previous to any trial or pain of seeking the beloved. The light must be tried; Psyche must doubt and seek to know; reading must become life and writing; and all go wrong. (HD 81)

Eros is also implicated in this reading because "the meaning of things seems to change when we fall in love, as if life were a language we had begun to understand" (HD 83). According to Duncan: "In the virtue of words that what were forces become meanings and seek form. Cosmic powers become presences and even persons, having body to the imagination. We fall in love with Love" (HD 83). As a cosmic power Eros is a libidinal force in Duncan's poetics, underscoring his conviction that "Writing is first a search in obedience" (OF 12):

The poet is not master of reality but its lover; and falling in love, charmed by reality, returns in the midst of that claim to fulfil [ $\mathrm{sic}$ ] the law of the poem itself. Only in the poem as he actually makes it will the Poetry that moves him come into existence. (FC 54)

Such a manifestation happens in Duncan's account of "Poem Beginning with a Line by Pindar" which as well as telling the story of Psyche's love also becomes the occasion of that story, via a misreading of Pindar's first Pythian Ode:

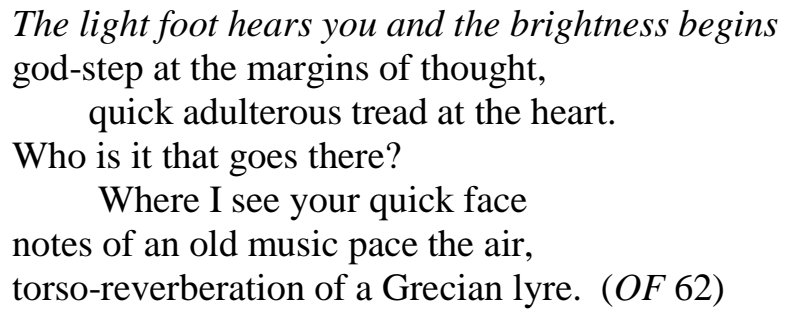

In these opening lines, as Duncan explains in "The Truth and Life of Myth," "cosmic powers" manifest as presences.

When, in the inception of "A Poem Beginning with a Line by Pindar," reading late at night the third line of the first Pythian Ode in the translation of by Wade-Grey and Bowra, my mind lost the hold of Pindar's sense and was faced with certain puns, so that the words light, foot, hears, you, brightness, begins moved in a world beyond my reading, these were no longer words alone but also powers in a theogony, having resonances in Hesiodic and Orphic cosmogonies where the foot that moves in the dance of the poem appears as the pulse of measures in first things. (FC 17)

Duncan's retrospective account of the poem's inception indicates how re-reading can "arouse in a contemporary consciousness reverberations of old myth" pertinent to the story of Eros and Psyche (HD 79):

Immediately, sight of Goya's great canvas, once seen in the Marquis de Cambo's collection in Barcelona, came to me, like a wave, carrying the vision — out of evocation to add their masterly powers to my own - the living vision, Cupid and Psyche were there; then, the power of a third master, not a master of poetry or of picture but of story-telling, the power of Lucius Apuleius was there too. In the grand theurgy of picture and story, the living genius of these three stood as my masters, and I stood in the very presence of the story of Cupid and Psyche-but in the power of those first Words - Light, Foot, Hears, You, Brightness, Begins-He was the primal Eros, and she, the First Soul. (FC 17) 
In tracing these powers back to the primary story of the primal Eros and the first Soul, Duncan performs a kind of $t a$ ' $w \bar{l} l$. And, like $t a$ ' $w \bar{l} l$, his reading is also interceded by an angelic figure and "the intuition of an essence or person in an Image which partakes neither of universal logic nor of sense perception, and which is the only means of signifying what is to be signified" (Alone 13).

\section{Interpreting Angels}

In "Towards an Open Universe," Duncan explains how "the germ of the poem quickened" by misreading Pindar: "[I]t was my inability to understand that began the work or it was the work beginning that proceeded the words I was reading in such a way that they no longer belonged to Pindar's Pythian I' (FC 86). Duncan echoes Harold Bloom's ideas about the creative contingencies of reading which, he reasons, is "a belated and all-but-impossible act, and if strong, is always a misreading" (3). Duncan frequently compares his own reading to Jacob wrestling the Angel in the Book of Hosea (12:4). In "The Law I Love is Major Mover" Duncan evokes Jacob's wrestle in the context of an "angelic Syntax" which he develops further in "The Structure of Rime 1," proposing that Jacob "wrestled with Sleep like a man reading a strong sentence" (OF 12). And, in "The Truth and Life of Myth," Duncan claims that, "I have come to think of Poetry more and more as a wrestling with Form to liberate Form" (FC 8).

Not only is Duncan's "Pindar" poem an instance of the poet wrestling with Pindar's "strong" sentence, it is also an angelic encounter. In misreading Pindar "a higher reality" intruded, Duncan claims: "I had mistaken the light foot for Hermes the Thief, who might be called The Light Foot, light-fingered, light-tongued" (OF 86). As messenger of gods Hermes assumes an angelic function which, Karl Kerényi suggests, is reflected in the word "hermeneutics":

Hermes is hermeneus ("interpreter"), a linguistic mediator, and this not merely on verbal grounds. By nature he is the begetter and bringer of something light-like, a clarifier, God of exposition and interpretation (of the kind that we are engaged in) which seeks and in his spirit [...] is led forward to the deepest mystery. (145-146)

Kerényi recalls "the interpreting angel" of the Recital who manifests in the "familiar Gnostic figure of the angelic Helper and Guide" (AV 23). Like Hermes, this "interpreting angel" is the linguistic mediator of a text's "esoteric" mysteries. Without this Guide "the soul cannot restore, return the text to its truth, unless it too returns to its truth (Haqiqat) which implies for it passing beyond imposed patencies, emerging from the world of appearances and metaphors, from exile and the 'Occident"' (AV31). Like Socrates' daemon, Hermes intercedes as the intermediary of a divine, Erotic, power. But in leading the poet back to "the transcendent reality of Eros and Psyche" this god also reflexively guides the poet through the poem's genesis, making Duncan's poem both the subject and object of its own recital by dramatizing its compositional processes ( $F C$ 17).

Obeying Hermes's intercession, Duncan becomes master and servant of his poem, following Hermes's lead. This recalls how Orphèe in Jean Cocteau's film, Orphèe (1950), blindly follows Heurtebise through the Underworld:

In Cocteau's film Orpheus the guardian angel Heurtebise tells Orpheus not to try to understand but to follow. It is a law in the reading of poetry that is a law too in the writing. Unless we follow, unless we follow thru the work to be done, there is no other way of understanding. Participation is all (HD 272).

Adumbrating the "gnostic revelations" of "Circulations of the Song," which are also mediated by a daemonic Hermes, the poet is led to participate in the primary ground of Eros ( $G W 174)$ :

We are drawn to Him, but we must also gather Him to be. We cannot, in the early stages, locate Him; but He finds us out. Seized by His orders, we "fall in love", in order that He be; and in His duration the powers of Eros are boundless. We are struck by His presence, and in becoming 
lovers we become something other than ourselves, subjects of a daemonic force previous to our humanity [.] (HD 82)

Duncan not only reiterates Psyche's passion but also the condition of every individual who "falls" in love. A similar fall, for example, occurs in "The Torso":

$$
\begin{aligned}
& \text { I have fallen in love. He } \\
& \text { has brought me into heights and depths my heart } \\
& \text { would fear without him. (BB 64) }
\end{aligned}
$$

Recalling the mediatrix of the Fedeli d'amore, the Beloved in Duncan's poem announces that, "you do not yet know but through me" ( $B B$ 64). What may seem narcissism leads to a more inclusive and encompassing gnosis, as Duncan indicates in "Circulations of the Song": "I am falling out into that Nature of Me / that includes the Cosmos it believes in" (170). Consequently, in the palpable figure of the Beloved, there is affirmation of Duncan's belief that, "We ourselves in our actuality, as the poem in its actuality, its thingness, are facts, factors, in which It makes Itself real" ( $B B$ vii). Falling in love, enacts a cosmological event of "fallen love" - epitomized in the passion of Psyche and Eros - that through the medium of a Beloved reunites the lover with Love, although, that mediator may not necessarily be a person. For, as Corbin proposes in Spiritual Body and Celestial Earth, "The earth is [also] an Angel" (3). But, whatever form it takes, that Beloved, as Duncan tells Ekbert Faas, is only recognized by "a searching Psyche" (81):

As long as a person is in love with and curious about and searching for the universe, he is engaged in language. And language has to increase for him to get anywhere in the universe. The symptom of ceasing to be in language, of ceasing to wander and talk is a de-reification of the universe and a letting go of everything around you. (83)

As Duncan's poetry repeatedly affirms, it is by being in love that makes "things about us reveal depths and heights of meaning" and makes us "involved in the sense of Creation ourselves" (FC 145). For this reason Duncan considers Psyche and Eros the "personae of a drama or dream that determines, beyond individual consciousness, the configurative image of a species" that dramatize "the inner works of the poetic opus" and "the great myth or work," that is, "the fiction of what Man is" $(H D 80,79)$. By its very nature, as Duncan's poetry attests, falling in love is itself a Recital of this poetic opus of fallen love that precipitates a redemptive corollary gnosis.

Notes

${ }^{1}$ Duncan's poem "WHOSE [Passages]" in Ground Work II: In the Dark (1987) is dedicated to Hillman, whose work in depth psychology also owes a considerable debt to Corbin. "I have a passage in 'Passages," Duncan claims in "Opening the Dreamway," "and that is the place where I thought I saw the soul" (24).

${ }^{2}$ Avicenna and the Visionary Recital is Willard R. Trask's English translation of the second edition of Corbin's book Avicenne et le récit visionnaire which was first published in 1954.

${ }^{3}$ This occurs in the ninth chapter of "Nights and Days," the second book of The H.D. Book, which Duncan wrote in March 1961. Chicago Review eventually published the chapter in 1979 without subsequent revisions (HD 648).

${ }^{4}$ Using Dante Gabriel Rossetti's translations of the early Italian poets in his chapter "Lingua Toscana," Swinburne's translation of Villon in "Moncorbier, alias Villon" and Pater's translation of "The Marriage of Cupid and Psyche" 
from Apuleius' the Golden Ass, in “The Phantom Dawn," Pound, in The Spirit of Romance, also bridges Victorian romanticism and early twentieth-century modernism.

${ }^{5}$ As well as Rumi, "Circulations of the Song" also more covertly recalls Cavalcanti's erotic imagery. For example, Duncan's "An arrow from the shining covert of your gaze / pierced me," adumbrates Cavalcanti's, "You pierced my heart by passing through the eyes / And woke the mind that slumbered unaware" ( $G W 173$; Cavalcanti 31).

\section{Works Cited}

Anderson, William. Dante the Maker. London: Routledge and Kegan Paul, 1980. Print.

Apuleius, Lucius. The Metamorphosis or Golden Ass of Apuleius. Trans. Thomas Taylor. Birmingham: W. J. Cosby, 1893. Print.

Bartlett, Lee, ed. “'Where as Giant Kings We Gatherd': Some Letters from William Everson to Robert Duncan, 1940 and After." Sagetrieb 4 2/3 (1985): 137 - 174. Print.

Bertholf, Robert J. and Albert Gelpi, eds. The Letters of Robert Duncan and Denise Levertov. Eds. Robert J. Bertholf and. Stanford, CA: Stanford UP, 2004. Print.

Bloom, Harold. A Map of Misreading. Oxford: Oxford UP, 2003. Print.

Boase, Roger. The Origin and Meaning of Courtly Love: A Critical Study of European Scholarship. Manchester: Manchester UP, 1977. Print.

Brown, Norman. O. The Challenge of Islam: The Prophetic Tradition. Ed. Jerome Neu. Santa Cruz, CA: New Pacific Press, 2009. Print.

Butterick, George. F. A Guide to The Maximus Poems of Charles Olson. Berkeley: U of California P, 1980. Print.

Cavalcanti, Guido. Complete Poems. Trans. Andrew Mortimer. Richmond, Surrey: Oneworld Classics, 2010. Print.

Chambers, Frank M. An Introduction to Old Provençal Versification. Philadelphia: American Philosophical Society, 1985. Print.

Cheetham, Tom. The World Turned Inside Out: Henry Corbin and Islamic Mysticism. Woodstock, CT: Spring Journal Books, 2003. Print.

Corbin, Henry. Alone with the Alone: Creative Imagination in the Süfism of Ibn 'Arabì. Trans. Ralph Manheim. Princeton, NJ: Princeton UP, 1997. Print.

- Avicenna and the Visionary Recital. Trans. Willard R. Trask. London: Routledge and Kegan Paul, 1961. Print. Cited as $A V$.

—. Cyclical Time and Ismali Gnosis. London: Kegan Paul International, 1983. Print.

- Spiritual Body and Celestial Earth: From Mazdean Iran to Shi ‘ite Iran. Trans. Nancy Pearson. London: I.B. Tauris, 1990. Print.

—. Temple and Contemplation. London: Routledge and Kegan Paul, 1986. Print.

- The Voyage and the Messenger: Iran and Philosophy. Berkeley: North Atlantic Books, 1998. Print. 
Davenport, Guy. Twelve Stories. Washington D.C.: Counterpoint Press, 1997. Print.

Davidson, Michael. "A Book of First Things: The Opening of the Field." Robert Duncan: Scales of the Marvelous. Eds. Robert J. Bertholf and Ian W. Reid. New York: New Directions, 1979. 56-84. Print.

_. "Marginality in the Margins: Robert Duncan's Textual Politics." Contemporary Literature 33. 2 (1992):

275-301. Print.

- The San Francisco Renaissance: Poetics and Community at Mid-Century. Cambridge: Cambridge UP, 1999. Print.

De Rougemont, Denis. Love in the Western World. Trans. Montgomery Belgion. Princeton, NJ: Princeton UP, 1983. Print.

Deghaye, Pierre. "Jacob Boehme and His Followers.” Trans. Katherine O’Brien and Stephen Voss. Modern Esoteric Spirituality. Eds. Antoine Faivre and Jacob Needleman. London: SCM, 1993, 210-247. Print.

Duncan, Robert. A Selected Prose. Ed. Robert J. Bertholf. New York: New Directions, 1995. Print.

- Bending the Bow. New York: New Directions, 1968. Print. Cited as BB.

- Fictive Certainties. New York: New Directions, 1985. Print. Cited as FC.

- Ground Work: Before the War. New York: New Directions, 1984. Print. Cited as GW.

- Ground Work II: In the Dark. New York: New Directions, 1987. Print.

—.The H.D. Book. Eds. Michael Boughn and Victor Coleman. Berkeley: U of California P, 2011. Print. Cited as $H D$.

—. "Opening the Dreamway," Spring 59: A Journal of Archetype and Culture (1996): 1- 45. Print.

- The Opening of the Field. New York: New Directions, 1973. Print. Cited as OF.

- Roots and Branches. New York: New Directions, 1964. Print. Cited as RB.

Faas, Ekbert. Towards a New American Poetics: Essays and Interviews. Santa Barbara, CA: Black Sparrow Press, 1978. Print.

Finkelstein, Norman. The Utopian Moment in Contemporary Poetry. Revised Ed. Cranbury, NJ: Associated UP, 1993. Print.

Fredman, Stephen. Contextual Practice: Assemblage and the Erotic in Postwar Poetry and Art. Stanford, CA: Stanford UP, 2010. Print.

Hewett, Greg. "Revealing 'The Torso': Robert Duncan and the Process of Signifying Male Homosexuality." Contemporary Literature 35.3 (1994): 522-546. Print.

Kerényi, Karl. Hermes: Guide of Souls. Trans. Murray Stein. Putnam, CT: Spring Publications, 1995. Print.

Olson, Charles. The Maximus Poems. Ed. George F. Butterick. Berkeley: U of California P, 1982. Print.

Pound, Ezra. Literary Essays. Ed. T. S. Eliot. London: Faber, 1954. Print. 
. Selected Prose: 1909-1965. Ed. William Cookson. London: Faber, 1978. Print.

T. The Spirit of Romance. London: Peter Owen, 1970. Print. Cited as SR.

Preda, Roxana. "The Broken Pieces of the Vessel: Pound and Cavalcanti." Ezra Pound and Poetic Influence: The Official Proceedings of the 17th International Ezra Pound Conference held at Castle Brunnenburg, Tirolo di Merano. Ed. Helen May Dennis. Amsterdam: Rodopi, 1994: 39-54. Print.

Quasha, George, Charles Stein, and Robert Kelly. “ $T a$ 'wīl or How to Read: A Five-Way Interactive View of Robert Kelley.” VORT 5 2.2 (1974): 108-134. Print.

Versluis, Arthur. Theosophia: Hidden Dimensions of Christianity. Hudson, NJ: Lindisfarne Press, 1994. Print. 